\title{
The carrying capacity for the development of marine ecotourism
}

\section{Daya dukung pengembangan ekowisata bahari}

\author{
Ilham Junaid \& Andi Nur Fauziah \\ Politeknik Pariwisata Makassar \\ Address: Jalan Gunung Rinjani, Tamalate, Makassar City, South Sulawesi 90224 \\ E-mail: illank77@yahoo.co.id \& andinurfauziah@gmail.com \\ Phone: 085256995927/085342589897
}

\begin{abstract}
Tanjung Karang in Donggala Regency has the potential to be developed based on the concept of marine ecotourism. However, the management tends to be contradictory with the principles of marine ecotourism. The aim of this research is to understand the supporting factors and challenges in implementing marine ecotourism in Tanjung Karang, as well as studying the carrying capacity and human resources. A qualitative research method was used through interviews and participant observation. The research shows that natural potential and traditional socio-cultural activities conducted by the community are both essential in supporting Tanjung Karang as a channel of marine ecotourism. The three management systems supported by the community, government and private sector are capable of making a difference in relation to marine ecotourism implementation. In building tourism facilities, people tend to ignore the environmental preservation aspect. In addition, the private sector, as one of the tourism developers, also needs to ensure the management of Tanjung Karang that they will provide opportunities for the local community to enjoy nature and the culture offered. This tourism should not be exclusively for international tourists. Although Tanjung Karang has been utilised as tourism attraction, marine ecotourism has not been prioritised by related stakeholders. Efforts have been done to support the implementation of marine ecotourism, however, the stakeholders need to understand supporting factors and challenges as well as carrying capacity in order to develop Tanjung Karang as marine ecotourism.
\end{abstract}

Keywords: Tanjung Karang; carrying capacity; marine ecotourism

\begin{abstract}
Abstrak
Tanjung Karang di Kabupaten Donggala memiliki potensi untuk dikembangkan berdasarkan konsep ekowisata bahari. Namun, pengelolaannya cenderung tidak sejalan dengan harapan atau prinsip ekowisata bahari. Penelitian ini bertujuan untuk mengetahui faktor-faktor penunjang dan penghambat penerapan ekowisata bahari di Tanjung Karang serta mengkaji daya dukung fisik dan sumber daya manusia. Untuk mencapai tujuan tersebut, penulis menerapkan metode kualitatif dengan pengumpulan data melalui wawancara dan observasi partisipatif. Hasil penelitian menunjukkan bahwa potensi alam dan aktifitas tradisional masyarakat dapat menjadi penunjang ekowisata bahari, namun tiga cara pengelolaan (oleh masyarakat, pemerintah dan swasta) menjadikan Tanjung Karang berbeda dalam hal implementasi prinsip ekowisata bahari. Pembangunan fasilitas wisata oleh masyarakat cenderung tidak memerhatikan aspek pelestarian lingkungan. Sebaliknya, pihak swasta memastikan bahwa ekowisata bahari diterapkan untuk memberikan kesempatan kepada seluruh komponen masyarakat untuk menikmati alam dan budaya, tidak semata-mata untuk wisatawan asing. Meskipun telah dimanfaatkan sebagai aset wisata, konsep ekowisata bahari belum menjadi prioritas para pemangku kepentingan (stakeholder) di daerah tersebut dan telah ada upaya atau langkah dalam mewujudkan tujuan ekowisata bahari, para stakeholder perlu memahami faktor pendukung dan penghambat agar daya dukung fisik dan sumber daya manusia di Tanjung Karang dapat dikembangkan berdasarkan konsep ekowisata bahari.
\end{abstract}

Kata kunci: Tanjung Karang; daya dukung; ekowisata bahari; pelestarian lingkungan

\section{Introduction}

Donggala Regency, in the Central Sulawesi Province, is known as one of the tourist destinations that has cultural potential or heritage. Historically, Donggala Regency was the centre of Dutch colonial government, as shown by the remnants of physical relics, such as old buildings that had value during the colonial period. The use of the Donggala area as the centre of the commercial and passenger ports 
by the Dutch government during the colonial era made this area has cultural and natural (marine) assets that potentially can attract tourists to visit. Tourists can also explore the natural beauty of the Donggala District, as well as experience and obtain knowledge about colonial history.

Donggala Regency currently has made use of the existence of Tanjung Karang, a region and tourist area that receives both domestic and international tourist. Tanjung Karang is a landscape with the beach serving as the major tourist attraction, in addition to some of its unique natural scenery and several supporting facilities. Based on this potential, Tanjung Karang is a natural tourism experience marine sports activities such snorkelling, diving, swimming as well as leisure activities such as enjoying boat recreation and sunset.

Along with the tourism potential, the implementation of the marine ecotourism concept needs to be studied in-depth. The tourists' visit to natural attractions provides the opportunity for a destination to develop ecotourism and hence, ecotourism grows rapidly in many destinations (Jones 2005, Kontogeorgopoulos \& Chulikavit 2010). Tourism could provide an economic impact for its people through employment opportunities (Hall \& Page 2006, Junaid 2017, Reindrawati 2017), especially marine ecotourism. The concept of ecotourism is believed to be an approach that helps to achieve sustainable tourism (Barkauskiene \& Snieska 2013, Orams 2002, Tsaur et al. 2006). Therefore, marine ecotourism has become an alternative for an area to make its marine potential further bring in a positive value, both to the economy and to the environmental conservation.

The implementation of marine ecotourism in Tanjung Karang tends to be only conceptual. The potential magnitude in Tanjung Karang leans towards not being in line with the expectations or principles of marine ecotourism. This can be seen from the coastal, management that ignores the aspect of environmental sustainability, particularly related to the environmental carrying capacity and the people who inhabit the area. Although the local community benefits economically from the arrival of the tourists, nevertheless, the value of conservation and the environmental balance must be maintained. Early observations show that a community trying to seek the benefits of existing tourism potentials can reduce the meaning of nature or the impact of environmental conservation. Even though the communities around Tanjung Karang know and agree on the importance of community engagement and environmental conservation, the reality tends to be the opposite based on the hopes and knowledge of the community.

This study aims to determine the supporting and inhibiting factors to do with the implementation of marine ecotourism in Tanjung Karang, as well as reviewing and describing the carrying capacity of the physical and human resources which are related to tourism. An understanding of carrying capacity is very important in order to propose an effort to apply marine ecotourism principles in Tanjung Karang. As a result, there are two research questions that will guide analysing the factual condition of Tanjung Karang tourism. The questions are 1) 'What are the supporting and inhibiting factors derived from the implementation of marine ecotourism in Tanjung Karang?' and 2) 'How do the physical and human resources support the application of marine ecotourism in Tanjung Karang?'

Carrying capacity or community capacity has several definitions. Hounslow (2002) argues that carrying capacity is defined as the ability of individuals, institutions (organisations) and communities to organise and manage everything related to the business, and its affairs and works collectively in order to strengthen and sustain positive changes. This definition assumes that the carrying capacity of the community is concerned with various aspects of human life and the ability to organise it to achieve the expected goals. Balint (2006:14) argues that community capacity is about "the level of competence, ability and necessary skills to set and achieve the relevant goals".

The concept of ecotourism can be understood through three indicators or criteria. These indicators are the travelling process to the natural tourist attraction, environmental conservation and the sustainability and local community prosperity of the destination (Blamey 2001, Cater 2004, Wood 2002). Tourists can gain experience and knowledge about the nature and the people's culture of the destination (Fennell 2015). Environmental preservation becomes the second principle of ecotourism, since the tourists not only enjoy the nature of a destination, but also they can learn and understand 
about the region's cultural potential. The principle of ecotourism also expects an effort to be made to optimise the involvement of the local residents in order to maintain the existence of a nature-based tourist attraction through the role of society.

Marine ecotourism implies making the maritime potential a tourist attraction by looking at the three aforementioned principles. The purpose of marine ecotourism is to promote sustainable tourism (Butcher 2007, Cater 2004, Tao 2010). Therefore, the concept would be implemented in the form of providing guidelines for visitors or tourists, and providing a learning experience as well as encouraging the management, owner and businesses to provide opportunities for the community and local residents. In other words, marine ecotourism covers the principles of sustainable tourism, which consists of the contribution towards the preservation of natural and cultural heritage, community involvement in tourism planning and tourist activities for the local people's economic benefit, along with providing interpretations about the existence of the cultural and natural heritage of a particular destination. It is important to support visit by independent travellers or tourists and well-organised groups of visitors (UNEP 2002).

The research conducted in the field of ecotourism has been widely studied by various academics looking at different perspectives (Almeyda et al. 2010, Manyara \& Jones 2007, Wyman \& Stein 2010). Almeyda's (2010) research study, for example, considers the presence of an eco-lodge as an example of successful ecotourism management in Costa Rica. This study considers that the presence of eco-lodge has a positive impact on environmental conservation and generates an income for the local people. The eco-lodge is run by taking into account the aspects of community advantage and environmental sustainability. The concept of marine ecotourism can be a reference for the stakeholders in an area, including Tanjung Karang in Donggala District, to manage the potential of the existing area. In other words, each region has an opportunity to be developed based on the principle of marine ecotourism if there is an effort to achieve those objectives.

Pegas, Coghlan, \& Rocha (2012) conducted research in Brazil with a focus on how to teach the local community, especially the children, about the importance of conservation and ecotourism. The results showed that ecotourism is believed to be an important strategy in encouraging the conservation of living things (biodiversity). This means that ecotourism approaches can be applied in Indonesia with a focus not only on the tourists, but also on the local communities. In other words, besides teaching the tourists about the conservation of living things or the environment, local people should be taught about eco-tourism principles (Wang \& Tong 2012).

\section{Research Method}

To answer the formulated questions drawn from the research problems, the authors employed a qualitative approach. The purpose was to know and assess the phenomena or facts that particularly related to socio-economics within the ecotourism field (Almeyda et al. 2010). The visit to this area was conducted in August 2015, in order to do the data collection by staying in Tanjung Karang for two days. The research was carried out after the researcher conveyed the research purpose to the Donggala Regency Department of Culture and Tourism. This was done in order to receive grant permission (recommendation) from the local government to collect information that related to the research objectives.

Research data were collected through in-depth interviews with staff or cottage managers (also serving as tourist guides) in Tanjung Karang who had experience working in the tourism field. In-depth interviews were also carried out with other accommodation management staff and local Tourism Office managers. The interviews took approximately 45-60 minutes and they also provided important information about the factual condition of Tanjung Karang as well as the tourism-related problems. In addition, the researcher also conducted informal interviews with Tanjung Karang staff, such as with transportation service providers (boat operators) and the local community members. 
Data collection was also done through participant observation by using the note-taking strategy along with documentation (taking pictures) in order to be able to undertake the research data interpretation.

The data obtained was then analysed by applying a transcription process to the interview results and analysing the records and information from the observation. The purpose of the transcription was to facilitate the author to reduce the data by paying attention to the simplification data approach, the presentation (interpretation) and conclusion. The process of identifying the main themes, concepts and categorisations that existed in the data was a step undertaken when conducting the qualitative data analysis (Spencer et al. 2003, Ritchie et al. 2003) which then resulted in the interpretation and conclusion.

\section{Result and Discussion}

\section{Tanjung Karang: Geographical conditions and tourism potential}

Geographically, Tanjung Karang is located in Labuan Bajo Urban Village in the Banawa District, Donggala Regency, in the Central Sulawesi Province. The Central Sulawesi province is made up of ten districts with 1,402 islands, which supports the area as a tourist destination. Donggala district has natural potential (especially for coastal or marine tourism) and culture. Tanjung Karang is a beach area that is located in Palu Bay, about three kilometres from Donggala city. Tanjung Karang has become one of the tourist attractions in Donggala, with three types of management area; government, society and private.

To reach Tanjung Karang, tourists travel about 15 minutes from Donggala downtown or about 34 kilometres from Palu city, the capital of Central Sulawesi Province. Private or rented transportation turned out to be the most common choice for tourists visiting Tanjung Karang. There is no public transportation that can bring tourists to the Tanjung Karang area. Concerning the roads, the conditions are good enough and make the journey much better, as it also means that the accessibility already supports making Tanjung Karang a tourist attraction.

In terms of the attractions or tourist activities in Tanjung Karang, the researchers divided them into two parts; the main tourist attraction and the supporting tourist attraction. Tanjung Karang has various tourism potentials that can be categorised as the main tourist attraction. The supporting tourist attraction is located around the Tanjung Karang area that is also visited by the tourists such as Pasoso Island, Tanjung Kapal Karam and Pulau Pasir Putih. The white sand and coral reef are potentials that can attract foreign and domestic tourists to come. Beach activities such as hiring a banana boat with a maximum of four people can be enjoyed by tourists at a cost of about IDR 25,000/person. For snorkelling and diving activities, tourists can rent the equipment at a cost of about IDR 25,000. In addition, tourist taxis offer the experience of exploring the coastal waters in Tanjung Karang with a tariff of IDR 100,000 for one trip with ten people.

\section{Supporting and inhibiting factors for marine ecotourism}

Tanjung Karang has been promoted and used as a tourist attraction by the community, government and tourists alike. As a tourism asset, the management system cannot be separated from the supporting and inhibiting factors or challenges that hold up the application of the concept of marine ecotourism in Tanjung Karang. For the supporting aspects, Tanjung Karang has a clean and clear beach which allows the tourists to see the natural beauty of the sea. In the marine ecotourism perspective and when it comes to nature conservation, this natural condition needs to be maintained in order to sustain it, so then it can continue to serve as a tourist attraction. This condition is a sign that the concept of tourism development should not be disrupted or disturbed by the tourist's irresponsible behaviour. In other words, the sustainability of the marine ecotourism concept depends on the presence of tourists or visitors who do not damage the clean environment. 


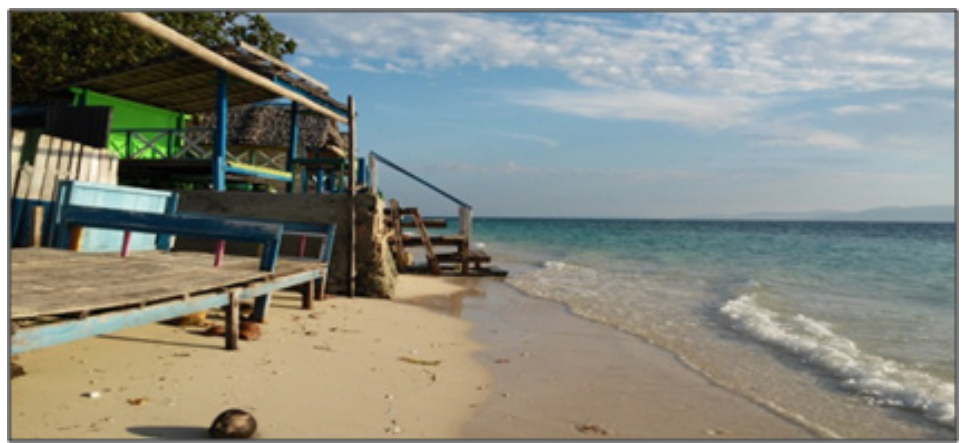

Figure 1.

The construction of a gazebo close to the shoreline Source: Personal Data 2015

Concerns seem to occur at some locations in Tanjung Karang. It was noted that the western coastal area has been littered with both plastic waste and tree twigs. From the informal interviews conducted, people said that the garbage comes from the river. Although it is not originally coming from there, still, it cannot be separated from the use of plastic by humans who then dispose of it irresponsibly. This condition turned out to be one of the obstacles of the realisation of the marine ecotourism principle in Tanjung Karang. Therefore, it takes effort to prevent the disruption of the marine ecosystem because of scattered waste.

The management process in Tanjung Karang has involved various community groups such as the government, the local community and private parties. The people of Tanjung Karang have participated in tourism activities through providing accommodation services and boats for recreational activities, as well as dining and drinking facilities for the tourists. In addition, the public take advantage of the tourist visits to sell souvenirs, rent swimming equipment and other maritime sports tools. By looking at the economic perspective, the participation of these communities has provided benefits with the indicator of an increase in additional incomes, besides the facilitation of other jobs. It can serve as the supporting aspect in applying the marine ecotourism concept within the perspective of the local community, as the manager and people benefit from the tourism activities. In contrast, the involvement of the community to provide tourist services is less likely to pay attention to the sustainability aspects when it comes to the natural environment. For instance, the construction of the gazebo was built without regards to the principle of environmental comfort and the spatial pattern of the coastal environment, since they build the gazebo, lodging houses and other facilities close to the shoreline. It means that the facilities provided by the community are unorganised.

This condition becomes a drawback for the realisation of the marine ecotourism concept in Tanjung Karang. This is because the desire to obtain economic benefits is stronger than considering the application of the environmental sustainability principle, which can be seen from the irregularity pattern in the tourism facilities development. According to the Minister of Maritime Affairs and Fisheries Regulation No. 34 / PERMEN-KP / 2014 about coastal area planning and small islands, the management of Tanjung Karang is not in accordance with the mandate of the existing regulation. It indicates the importance of planning, utilisation, supervision and control of coastal resources and islands for the improvement of the people's welfare. The use of the beach should be intended for the public interest. In this case, the coastline (GSP) becomes a consideration when developing the beach as a tourist attraction. Judging from the tourist visit data to Tanjung Karang (see Table 1), it can be argued that the limited public space can be a barrier to the application of the marine ecotourism concept.

An increase in the number of tourist visits to Tanjung Karang generally happened in the holidays, especially Sunday. Visitors came in large numbers, limiting the tourists in being able to enjoy the nature of Tanjung Karang. That is to say, the principle of marine ecotourism, where there was a process, obtained knowledge and experience within a recreational atmosphere, but it cannot be 
realised to its fullest potential. Similarly, the environmental sustainability could also be disrupted, which makes the marine ecotourism concept unable to be achieved.

The area of Tanjung Karang can be divided into three parts, if seen from the perspective of the parties who involved in managing the tourist attractions in the coastal area. First, is the government, who host accommodation (cottages) for tourists. The government-owned accommodation business also has operational managers, which makes the government have two roles; as a tourism business actor and serving as a tourist area manager. Moreover, the society also plays a part in the tourism business. In other words, they also build the tourism business where the benefits and advantages are for their own interests. In addition, private parties also manage the areas where the profits are for the continuation of their business. An example is the Prince John Dive Resort, a tourism resort business that also uses part of the Tanjung Karang area.

Table 1.

Data of the tourist visits to Tanjung Karang in 2014

\begin{tabular}{clccc}
\hline No. & Month & Domestic Tourist & International Tourist & Total Number \\
\hline 1 & January & 4120 & 30 & 4150 \\
2 & February & 3940 & 27 & 3967 \\
3 & March & 4000 & 19 & 4019 \\
4 & April & 4435 & 15 & 4450 \\
5 & May & 4650 & 16 & 4666 \\
6 & June & 5400 & 18 & 5418 \\
7 & July & 8191 & 48 & 8239 \\
8 & August & 6900 & 43 & 6943 \\
9 & September & 5421 & 26 & 5447 \\
10 & October & 5301 & 37 & 5338 \\
11 & November & 9056 & 40 & 9096 \\
12 & December & 8322 & 39 & 8361 \\
& Total & 69736 & 358 & $\mathbf{7 0 0 9 4}$ \\
\hline
\end{tabular}

Source: Department of Culture and Tourism of Donggala Regency 2014

The three types of management style can be both a support and hindrance to the development of Tanjung Karang's marine ecotourism. If the government, communities and the private sector are aware of the importance of applying ecotourism principles, then the management will be a supporter of the development of the marine ecotourism concept. On the other hand, if the government, communities and the private sector are unable to ensure that their involvement in tourism activities will impede the implementation of marine ecotourism, then they will be an inhibitor. Therefore, an approach is needed to encourage that the three stakeholders implement marine ecotourism principles in Tanjung Karang.

\section{The implementation of marine ecotourism in Tanjung Karang: Physical supports and human resources}

From the observation of the use of Tanjung Karang as a tourism attraction, it can be said that the concept of marine ecotourism has been implemented. However, the implementation has not fully fulfilled the goal of marine ecotourism. The supporting and inhibiting factors as previously described have become the reason why constructive recommendations are needed. This then can bring in further support for marine ecotourism implementation. This study has looked at two important aspects for implementing marine ecotourism; physical carrying capacity (environment) and human resources. It can be seen from the physical environment that the factual condition of marine ecotourism in Tanjung Karang can be divided into two parts. First, the physical carrying capacity managed by the community which includes areas or regions where the government plays a 
role in managing the accommodation business. Tanjung Karang has an area of about $28.74 \mathrm{Ha}$ with various facilities that support tourism activities. The environmental or physical carrying capacity indicates a mismatch between the number of visitors when compared with the environmental condition. This means that the spaces are limited due to the irregular construction that makes Tanjung Karang, to a greater extent, unprepared for the carrying capacity of marine ecotourism. In other words, the excessive number of visitors makes the physical environment in Tanjung Karang decreases. Therefore, it requires a balance between the environmental areas that are used as a tourism asset with the number of visitors who come to use the area for recreational purposes.

Secondly, the private sector (the John Dive Resort) manages the Tanjung Karang area with a different approach. They seek to manage the area (including the sea) based on the sustainability principle. However, there are still efforts that do not take into account the balance when it comes to using the tourism area. In terms of environmental conservation, private parties are cultivating the coral reefs by drowning the iron frame. According to them, this effort can help to grow the coral reefs. Thus, within a certain time, the resort is able to contribute towards the improvement of marine biota life.

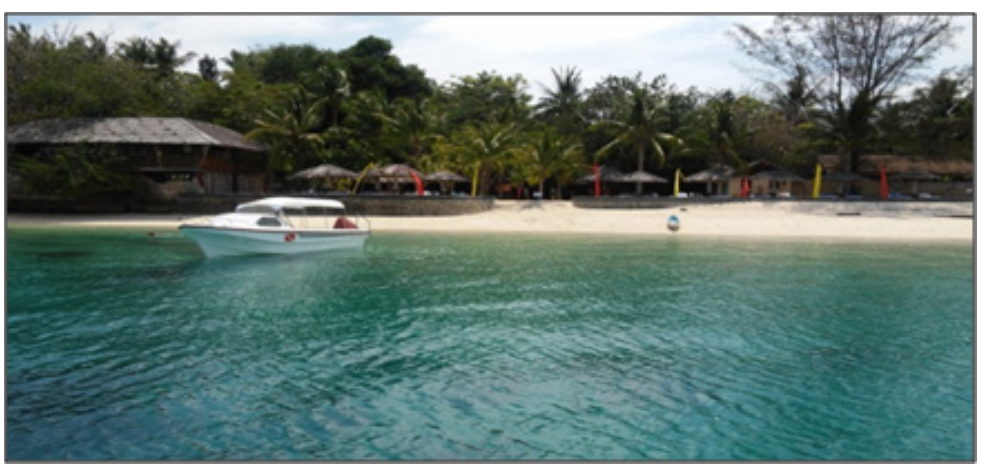

Figure 2.

The management of Tanjung Karang as a tourist attraction by the private sector Source: Personal Data 2015

In terms of the tourism attraction management policies, private parties tend to limit access for the general public when it comes to entering the resort. The opportunity to use the natural environment in the area is more exclusively for the upper middle class than the general public. The policies that are applied by the resort management tend to be used for the benefit of foreign parties. This situation is not in accordance with the principle of marine ecotourism, where people are given access to experience or learn in a manner that is related to nature. Otherwise, in terms of nature conservation, the resort's management should be an example for the general public on how to conduct and conserve nature.

In-depth interviews with the cottage managers (private) show that there is a perception that foreign tourists tend to be more aware of environmental preservation compared to local (domestic) tourists. The policy of not letting the general public enter the resort is motivated by an understanding and experience of the tourists' attitude and behaviour when they visit the destination. Although one of the objectives of the resort management is to maintain environmental sustainability without abandoning profit, the utilisation of nature as a tourist attraction for all of the components of society (both foreign and domestic tourists) should not be limited. Domestic tourists (public society) should be guided in understanding the concept of environmental conservation by providing strict guidelines while they are in the resort area. Therefore, management concerns about the irresponsible manner of domestic tourists can be avoided and minimised. From the human resources aspect, the community support capacity can be divided into several groups. First, the community of fishermen who live and depend on fishing activities. This community groups has been involved in and use tourism as an additional income, and there are several communities who only work as fishermen. They understand how they should preserve marine nature. The community groups that are already aware of the importance of the survival of marine nature need to be supported as they keep working on the principle of ecotourism. For instance, local people do not fish in protected areas. They realise that fishing in this 
location can disrupt conservation. Moreover, they are not fishing with tiger trawling systems and toxins because they know that it will disrupt the marine ecosystem. In addition to this, the presence of fishermen can be a driving force of marine ecotourism activities because they are local people who understand safety at sea when unexpected things happened to tourists, such as drowning, exposure to sea animals, and so on.

The second category is a group of people who rely solely on the provision of tourism services and the community groups living outside the area of Tanjung Karang. In relation to the social-cultural aspects, there is social jealousy between these two groups. Those who live outside the area tend to be unhappy with the current tourism activities since that they do not benefit from the tourist visits to Tanjung Karang because of the limited opportunities for them to gain any economic benefits. The opening of Tanjung Karang as a tourist asset is more useful for those who are living in the area. It is certainly unavoidable, given that the tourist destination is near to their house and they could gain numerous economic benefits from it. This situation will also have an impact on the level of public awareness in understanding the meaning of marine ecotourism.

The third group is those who work in private-run resorts. In terms of human resources, the resort staff may understand the principles of marine ecotourism. This can be shown in the services that they provide to the tourists which come from their learning process. Therefore, the carrying capacity of the human resources has potential and is ready to develop Tanjung Karang based on the marine ecotourism concept.

\section{Constructive recommendations for the marine ecotourism principles}

Tanjung Karang can be an example of a destination in Indonesia (including international) that is managing a marine ecotourism tourism attraction. Various stakeholders are needed to achieve these objectives. This research has recommended some strategic steps that can be undertaken by the stakeholders to make Tanjung Karang a model example of marine ecotourism management.

First, the Prince John Dive Resort (private) has human resources with various skills and expertise in managing the tourism business, taking into account the ecotourism aspect. This study considers that the role of the private sector is very important in ensuring that all elements apply the principles of marine ecotourism. Furthermore, the private sector have staff who have expertise in serving food, housekeeping and accommodation management, as well professional diving instructors, and staff who already know the importance of awareness when it comes to preserving the environment. In addition, from the resort side of things, they can actively engage in assisting the community who manage the Tanjung Karang area through counselling and mentoring activities.

The government has the role of providing signs or guidelines to the private parties who will invest in tourism. The role of the local government is also to provide the regulations that arrange and organise the investment climate including how to empower the existence of local communities who will gain from marine ecotourism. The advisory activities should be facilitated by the local government, as the one responsible for giving permission to carry out tourism business activities in Tanjung Karang. Supposedly, the private sector and the community are governed by local regulations when conducting activities or business in tourism. Therefore, the implementation of local government regulations becomes an urgent need in order to avoid irresponsible management activities.

The management of some areas in Tanjung Karang by the local government hold to the principles of environmental sustainability and bring in benefits for the local community. This effort has given the local community job opportunities as tourism staff. Those who have received education and training that is related to the tourism also have a moral responsibility to provide examples of tourism business management using ecotourism principles. Socialisation towards tourists has also been done by the local government. This is expected to have a positive impact on the community, who previously have not yet realised the importance of environmental conservation. 
Second, the rubbish that was found scattered in Tanjung Karang is not solely the task of society in isolation. The waste cannot be separated from the tourist's or visitors' behaviour. They tend to not to pay attention to enviromental sustainability. The principle of learning about natural conservation in relation to marine ecotourism needs to be applied by providing guidelines for the tourists. This is to provide the opportunity for visitors or tourists to obey the rules that are related to environmental conservation. By adhering to the educational sanctions, which support the tourist's responsible acts, they will pay attention to the cleanliness of the environment more. The concern of private parties towards the irresponsible behaviour of domestic tourists can be resolved by the application of guidelines and visiting rules.

Third, the carrying capacity of marine ecotourism in Tanjung Karang will be further supported by the sustainability of underwater parks that can be enjoyed by tourists. Moreover, beach activities are part of the attraction that tourists can enjoy, but ecotourism activities such as underwater scenery and conservation strategies are the main things of importance to note. To achieve this goal, tourism's collective awareness from both the community and government channels is required. This cooperation is related to the role of each society component in providing services to the tourists. The collective awareness is more focused on the role of society, since they directly interact with tourists. Various marine ecotourism activities can be done in Tanjung Karang that do not disturb the conservation of the marine biota and coral reefs. A brief overview of the constructive recommendations of this study can be seen in Diagram 1.

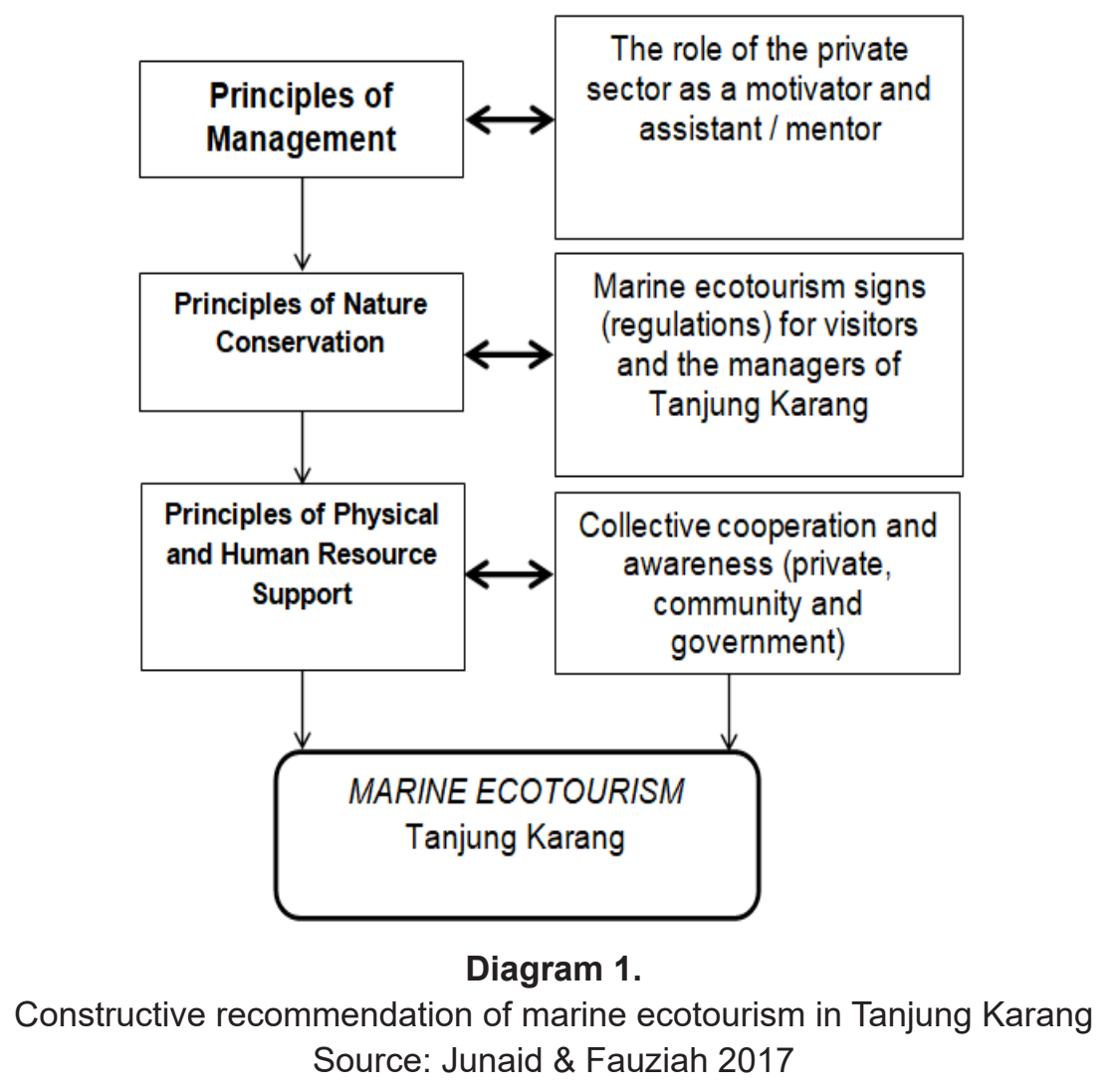

\section{Conclusion}

When an area has tourism potential that can be developed, various efforts will be made to support it. Tanjung Karang in Donggala District is one example of how stakeholder groups that include the government, the community and the private sector use nature for tourism. Although it has been utilised as a tourism asset, the concept of marine ecotourism has not been the priority of the stakeholders. The term 'tourism' is more widely used than 'marine ecotourism'. Even though in reality this shows that there have been efforts or steps towards realising the goal of marine ecotourism, the stakeholders 
need to understand the supporting factors and obstacles in relation to ecotourism in Tanjung Karang. Furthermore, this identification can provide some information about the carrying capacity of Tanjung Karang in the context of achieving marine ecotourism as well as the constructive recommendations that can be applied.

Physically, Tanjung Karang's natural environment has supported the implementation of marine ecotourism. However, the three routes of management (community, government and private) make Tanjung Karang different in terms of marine ecotourism principle implementation. The areas that are managed by the community, for example, pay less attention to the aspect of environmental sustainability because of the development of tourism facilities solely for the community groups' benefit. The limited space for tourists to enjoy nature in Tanjung Karang beach has become one of the obstacles to achieving the goal of marine ecotourism. In contrast, the private sector's management has noticed the environmental aspects despite the fact that the tourism facilities are destined for the benefit of foreign tourists. This condition requires effort to convince the public and private sectors that marine ecotourism needs to be applied in reality, not merely as a concept.

This research states the importance of the private sector's role by optimising the skills and professional capabilities within it in order to assist the community. The local governments need to apply regulations in order to regulate investors (entrepreneurs) and communities in managing the tourism business. This is based on the principles of sustainability (the conservation of nature and culture, a sustainable and balanced welfare community, along with tourism services which promote awareness of the importance of environmental sustainability). Furthermore, for the private sector roles, they are able to organise socialisation and training in collaboration with educational institutions to help communities optimise their potential. In addition, in relation to irresponsible tourist behaviour,

it should be regulated by applying rules and guidelines during the tourist's visit. The guidelines are expected to be useful to maintain the existence of the coral reefs and to help maintain the ongoing environmental conservation. Therefore, the collective cooperation and awareness of the various elements of society make Tanjung Karang a model or pilot management example of marine ecotourism.

\section{References}

Almeyda AM, Broadbent EN, Wyman MS \& Durham WH (2010) Ecotourism impacts in the Nicoya Peninsula, Costa Rica. International Journal of Tourism Research, 12:803-819. Doi: 10.1002/ jtr.797.

Balint PJ (2006) Improving community-based conservation near protected areas: The importance of development variables. Environmental Management, 38:137-148.

Barkauskiene K \& Snieska V (2013) Ecotourism as an integral part of sustainable tourism development. Economics and Management, 18 (3).

Blamey RK (2001) Principles of Ecotourism. In: DB Weaver (ed). The Encyclopedia of Ecotourism. Wallingford: CABI.

Butcher J (2007) Ecotourism, NGOs and Development: A Critical Analysis. London: Routledge.

Cater E (2004) Ecotourism: Theory and Practice. In: AA Lew, CM Hall, \& AM Williams (eds). A Companion to Tourism. Malden: Blackwell. 484-497.

Fennell DA (2015) Ecotourism (Fourth Edition). London: Routledge.

Hall CM \& Page SJ (2006) The Geography of Tourism and Recreation. London: Routledge.

Hounslow B (2002) Community capacity explained. Stronger Families Learning Exchange Bulletin, $1: 20-22$.

Jones S (2005) Community-based ecotourism: The significance of social capital. Annals of Tourism Research, 32 (2):303-324. doi:10.1016/j.annals.2004.06.007.

Junaid I (2017) Langkah strategis pengembangan indigenous tourism: Studi kasus di Kabupaten 
Kepulauan Selayar. Masyarakat, Kebudayaan dan Politik, 30 (3):266-277.

Kontogeorgopoulos N \& Chulikavit K (2010) Supply-side perspectives on ecotourism in Northerland Thailand. International Journal of Tourism Research, 12:627-641. doi: 10.1002/jtr.785.

Manyara G \& Jones E (2007) Community-based tourism enterprises development in Kenya: An exploration of their potential as avenues of poverty reduction. Journal of Sustainable Tourism 15 (6):628-644. http://dx.doi.org/10.2167/jost723.0.

Orams MB (2002) Marine ecotourism as potential agent for sustainable development in Kaikoura, New Zealand. International Journal of Sustainable Development, 5 (3):338-352. http://www. coastalmarineresearchgroup.com/PDFs/Orams\%202002\%20Marine $\% 20$ ecotourism $\% 20$ as $\% 20$ a $\% 20$ potential $\% 20$ agent $\% 20$ for $\% 20$ sustainable $\% 20$ development $\% 20 \mathrm{in} \% 20$ kaikoura\%20NZ.pdf.

Pegas F, Coghlan A, \& Rocha A (2012) An exploration of a mini-guide programme: Training local children in sea turtle conservation and ecotourism in Brazil. Jurnal of Ecotourism, 11 (1):4855 .

Reindrawati DY (2017) Tantangan dalam implementasi social entrepreneurship pariwisata di Pulau Madura. Masyarakat, Kebudayaan dan Politik, 30 (3):215-228.

Ritchie J, Spencer L, \& O'Connor W (2003) Carrying out qualitative analysis. In: J Ritchie \& J Lewis (eds). Qualitative Research Practice: A Guide For Social Science Students and Researchers. London: SAGE. 219-262.

Spencer L, Ritchie J, \& O'Connor W (2003) Analysis: Practices, Principles and Practices. In: J Ritchie \& J Lewis (eds). Qualitative Research Practice: A Guide For Social Science Students and Researchers. London: SAGE. 199-218.

Tao TCH (2010) Ecotourism and environmental sustainability: Principles and practice. Annals of Tourism Research 37:1190-1216. doi:10.1016/j.annals.2010.07.005.

Tsaur SH, Lin YC \& Lin JH (2006) Evaluating ecotourism sustainability from the integrated perspective of resource, community and tourism. Tourism Management, 27:640-653.

UNEP/WTO (2002) Quebec Declaration on Ecotourism. www.ecotourism2002.org.

Wood ME (2002) Ecotourism: Principles, Practices and Policies for Sustainability. [Accessed 14 October 2017]. http://tourisminsights.info/ONLINEPUB/ECOTOURISM/ ECOTOURISM\%20PDFS/ecotourism1.pdf.

Wang H \& Tong M (2012) Community Participation in Environmental Management of Ecotourism. In: JA Seba (ed). Ecotourism and Sustainable Tourism: New Perspectives and Studies, Toronto: Apple Academic Press. 38-44. 